\title{
Transcutaneous Partial Pressure of Oxygen Measurement in Advanced Chronic Venous Insufficiency as a Marker of Tissue Oxygenation
}

\author{
Ludia John ${ }^{1}$, Albert Abhinay Kota', Vimalin Samuel ${ }^{1}$, Prabhu Premkumar ${ }^{1}$, Dheepak Selvaraj ${ }^{1}$, \\ Edwin Stephen ${ }^{1}$, Sunil Agarwal ${ }^{1}$, and Pranay Gaikwad ${ }^{2}$ \\ ${ }^{1}$ Departments of Vascular Surgery and ${ }^{2}$ General Surgery Unit 1, Christian Medical College, Vellore, India
}

\begin{abstract}
Purpose: Determination of oxygen concentration in tissues affected by chronic venous insufficiency (CVI) has shown inconsistent results over the years and has confounded the pathophysiology of venous diseases. This study measured transcutaneous partial oxygen pressure $\left(\mathrm{TCPO}_{2}\right)$ levels in patients with $\mathrm{CVI}$ to assess oxygenation and variation in oxygenation according to CVI stage.

Materials and Methods: A prospective study was performed on consecutive patients with unilateral CVI. $\mathrm{TCPO}_{2}$ of diseased and unaffected limbs was measured in the supine and dependent positions. A single $\mathrm{TcPO}_{2}$ value was measured at the site of greatest skin change or at the edge of the ulcer. The $\mathrm{TCPO}_{2}$ values were analyzed and compared according to stage.

Results: A total of 96 patients were included in the study with C4 (24.0\%), C5 (19.8\%), and C6 (56.3\%) disease. The mean age was 44.7 years, and 85 (88.5\%) were male. There was a statistically significant $(\mathrm{P}<0.01)$ difference in mean $\mathrm{TcPO}_{2}$ levels between the unaffected limb (supine, $32.1 \mathrm{mmHg}$; dependent, $50.7 \mathrm{mmHg}$ ), C5 diseased limb (supine, $16.6 \mathrm{mmHg}$; dependent, $35.5 \mathrm{mmHg}$ ), and C6 diseased limb (supine, $24.2 \mathrm{mmHg}$; dependent, $40.4 \mathrm{mmHg}$ ). In the supine and dependent positions, the mean $\mathrm{TcPO}_{2}$ in the affected limb was significantly lower $(\mathrm{P}<0.01)$ than that in the unaffected limb.

Conclusion: $\mathrm{TCPO}_{2}$ in advanced $\mathrm{CVI}$ can be used as a marker of oxygenation status. This is the first study in an Indian population looking at the relevance of $\mathrm{TcPO}_{2}$ in the prognostication of advanced CVI.
\end{abstract}

Key Words: Venous insufficiency, Varicose veins, Varicose ulcer, Transcutaneous blood gas monitoring
Received January 6, 2021

Revised April 25, 2021

Accepted June 23, 2021

Published on July 12, 2021

Corresponding author: Albert Abhinay Kota Department of Vascular Surgery, Christian Medical College, IDA Scudder Rd, Vellore 632004 , India

Tel: +914162282085

Fax: +919789360870

E-mail: albert.cmc@gmail.com https://orcid.org/0000-0002-4313-803X

Edwin Stephen's current affiliation: Vascular Surgery Unit, Sultan Qaboos University Hospital, Muscat, Oman.

Copyright (C) 2021 The Korean Society for Vascular Surgery

This is an Open Access article distributed under the terms of the Creative Commons Attribution Non-Commercial License (http://creativecommons.org/licenses/by-nc/4.0) which permits unrestricted non-commercial use, distribution, and reproduction in any medium, provided the original work is properly cited.

Cite this article; Vasc Specialist Int 2021. https://doi.org/10.5758/vsi.210001

\section{INTRODUCTION}

Chronic venous insufficiency (CVI) commonly affects the lower limbs secondary to valvular incompetence, venous obstruction, or post-thrombotic phenomenon. While CVI is not a life-threatening disease, it can result in long-term morbidity with consequent financial and social implications. Due to a dearth of research on this issue, it is difficult to assess the prevalence of leg ulcers in India, which has a population of over 1.2 billion people [1]. In India, the estimated prevalence of leg ulceration was 4.5/1,000 population, with $\mathrm{CV} 1$ being a significant contributor; male sex and 
intermediate socioeconomic status were found to be risk factors [2,3].

Adequate tissue perfusion and oxygenation are prerequisites for wound healing. Factors hampering tissue oxygenation predispose patients to ulcer formation and persistence. In CVl, the microcirculation is impaired, resulting in skin changes and ulcer formation. There are few studies with conflicting results documenting the correlation between CVI and tissue oxygen [4-7], with none in the Indian population in the English literature. Tissue oxygenation can be estimated by measuring transcutaneous partial oxygen pressure $\left(\mathrm{TcPO}_{2}\right)$.

Measurement of oxygen tension in the tissue is a good tool for predicting wound healing post-amputation in arterial diseases [8]. In this study, $\mathrm{TcPO}_{2}$ in advanced $\mathrm{CVI}$ (stages C4 to (6) was measured and compared to the $\mathrm{TcPO}_{2}$ in the unaffected limb. Measurement of tissue oxygenation (hypoxia) in $\mathrm{CVl}$ using $\mathrm{TcPO}_{2}$ can help to better understand the disease process, prognostication, and compare the effectiveness of various treatment modalities. We hypothesized that tissue oxygenation, as represented by $\mathrm{TcPO}_{2}$, will progressively decrease from $\mathrm{C} 4$ to $\mathrm{C} 6$ according to the $\mathrm{CVI}$ severity.

\section{MATERIALS AND METHODS}

This prospective cross-sectional study was conducted at our teaching hospital between July 2014 and August 2016. The study was approved by the Institutional Review Board of the Christian Medical College (IRB no. 8994) and written informed consent was obtained from the patients. Based on the formula $(1.96)^{2} \times p q / d^{2}$ for observational cross-sectional prospective study, the required sample size was calculated to 96 ("p," i.e., prevalence, was taken to be $50 \%$; "q" = p-1; and " $\mathrm{d}$ " is the standard error [10\%]) [9].

Patients presenting to the vascular surgery department with unilateral CVI, C4 to C6, were screened and included in the study. All patients underwent duplex ultrasonography. Twenty-two patients were excluded from the study after screening because of bilateral limb disease, peripheral arterial disease, vasculitis, active limb infection, or pedal edema due to other causes (lymphedema, renal, or hepatic failure). $\mathrm{C} 3$ disease was also excluded because edema is known to alter the $\mathrm{TcPO}_{2}$ value [10]. The contralateral limb did not show any clinical symptoms or signs of CVI.

After obtaining informed consent, a detailed clinical examination was performed to confirm the diagnosis of $\mathrm{CVl}$, stage the disease according to the Clinical-EtiologyAnatomy-Pathophysiology classification [11], and rule out other causes of limb ulcers. A single $\mathrm{TcPO}_{2}$ measurement was taken in the supine and dependent (sitting) positions at the site of maximum skin change since it would reflect the lowest level of oxygenation corresponding to the site of maximal microangiopathic changes or the worst disease. In $\mathrm{C} 6$ disease, $\mathrm{TcPO}_{2}$ was measured close to the ulcer edge, while in $\mathrm{C} 5$ disease, it was measured close to the border of the scarred tissue. The $\mathrm{TcPO}_{2}$ value at the corresponding site of the opposite limb served as an internal control for that particular patient, thus matching patient-related confounding factors. Measurements were obtained in the vascular lab at an ambient temperature of $22^{\circ} \mathrm{C}$ to $24^{\circ} \mathrm{C}$. The electrode was attached with an adhesive ring to the site at a temperature of $43^{\circ} \mathrm{C}$. The physiological stabilization time of a patient is 15 to 20 minutes for $\mathrm{TcPO}_{2}$ reading. During this time, the electrode slowly heats the skin and dilates the arteries. The stable value after 20 minutes was recorded as the measurement for the analysis.

Data were analyzed using IBM SPSS statistics (version 21.0; IBM Corp., Armonk, NY, USA). Descriptive statistics, paired t-test, independent samples t-test, and Bonferroni analysis were performed. Statistical significance was set at $\mathrm{P}<0.05$.

\section{RESULTS}

Of the 96 patients, 59.4\% were above the age of 40 years (mean age, $44.7 \pm 11.7$ years; range, $25-73$ years). The study included 85 males and 11 females. Left-sided disease was present in $51(60.0 \%)$ males and $7(63.6 \%)$ females (Table 1).

A Shapiro-Wilk test and visual inspection of histograms, normal Q-Q plots, and box plots showed that the $\mathrm{TcPO}_{2}$ values of the affected and non-affected limbs were normally distributed when measured in the dependent position (skew-

Table 1. Descriptive statistics of patients included in study

\begin{tabular}{lccc}
\hline Characteristic & Male $(\mathrm{n}=85)$ & Female $(\mathrm{n}=11)$ & Total $(\mathrm{n}=96)$ \\
\hline Stage & & & \\
C4 & $20(23.5)$ & $3(27.3)$ & $23(24.0)$ \\
C5 & $18(21.2)$ & $1(9.1)$ & $19(19.8)$ \\
C6 & $47(55.3)$ & $7(63.6)$ & $54(56.3)$ \\
Side & & & \\
Right & $34(40.0)$ & $4(36.4)$ & $38(39.6)$ \\
Left & $51(60.0)$ & $7(63.6)$ & $58(60.4)$ \\
Age (y) & & & \\
$\leq 30$ & $11(12.9)$ & $2(18.2)$ & $13(13.5)$ \\
$31-45$ & $36(42.4)$ & $1(9.1)$ & $37(38.5)$ \\
$46-60$ & $31(36.5)$ & $6(54.6)$ & $37(38.5)$ \\
$>60$ & $7(8.2)$ & $2(18.2)$ & $9(9.4)$ \\
\hline
\end{tabular}

Values are presented as number (\%). 
Table 2. Comparison of supine and dependent mean $\mathrm{TcPO}_{2}$ values in unaffected and affected limbs

\begin{tabular}{cllc}
\hline Limb & \multicolumn{1}{c}{ Position } & $\mathrm{TcPO}_{2}(\mathrm{mmHg})$ & Paired t-test \\
\hline Normal & Supine $(\mathrm{I})$ & $32.05 \pm 11.16$ & \\
& Dependent $(\mathrm{J})$ & $50.74 \pm 11.89$ & \\
& Difference $(\mathrm{J}-\mathrm{I})$ & $18.69 \pm 6.83$ & $\mathrm{P}<0.01$ \\
Diseased & Supine $(\mathrm{I})$ & $23.28 \pm 11.52$ & \\
& Dependent $(\mathrm{J})$ & $40.50 \pm 12.22$ & \\
& Difference $(\mathrm{J}-\mathrm{I})$ & $17.12 \pm 6.68$ & $\mathrm{P}<0.01$ \\
\hline
\end{tabular}

Values are presented as mean \pm standard deviation.

Table 3. Comparison of mean $\mathrm{TcPO}_{2}$ in different stages of $\mathrm{CVI}$ and their significance in different positions (unit: $\mathrm{mmHg}$ )

\begin{tabular}{|c|c|c|c|c|}
\hline Position & $\begin{array}{l}\text { CVI stage }(\mathrm{I}) \\
\left(\text { mean } \mathrm{TcPO}_{2}\right)\end{array}$ & $\begin{array}{l}\text { CVI stage }(\mathrm{J}) \\
\left(\text { mean } \mathrm{TcPO}_{2}\right)\end{array}$ & $\begin{array}{c}\text { Mean } \mathrm{TcPO}_{2} \\
\text { difference }(I-J)\end{array}$ & P-value \\
\hline \multirow[t]{6}{*}{ Supine } & C0 (32.05) & C4 (26.57) & 5.48 & 0.187 \\
\hline & & C5 (16.63) & 15.42 & $<0.001^{*}$ \\
\hline & & C6 (24.22) & 7.83 & $<0.001^{*}$ \\
\hline & C4 (26.57) & C5 (16.63) & 9.94 & $0.022^{*}$ \\
\hline & & C6 (24.22) & 2.34 & $>0.999$ \\
\hline & C5 (16.63) & C6 (24.22) & -7.59 & 0.058 \\
\hline \multirow[t]{6}{*}{ Dependent } & CO (50.74) & C4 (44.83) & 5.91 & 0.182 \\
\hline & & C5 (35.47) & 15.27 & $<0.001^{*}$ \\
\hline & & C6 (40.43) & 10.31 & $<0.001^{*}$ \\
\hline & C4 (44.83) & C5 (35.47) & 9.36 & 0.063 \\
\hline & & C6 (40.43) & 4.40 & 0.791 \\
\hline & C5 (35.47) & C6 (40.43) & -4.96 & 0.681 \\
\hline
\end{tabular}

$\mathrm{CVI}$, chronic venous insufficiency.

*Statistically significant.

ness<0.35), but had significant skewness when measured in the supine position (affected limb, 0.729; non-affected limb, 0.814). However, parametric tests were employed in all cases, as they fulfilled the other required conditions for parametric tests.

In the supine position, irrespective of the stage of advanced $\mathrm{CVI}$, the mean $\mathrm{TcPO}_{2}$ in the affected limb (23.3 $\mathrm{mmHg}$ ) was significantly lower than that in the nonaffected limb (32.1 $\mathrm{mmHg} ; \mathrm{P}<0.01)$. In the dependent position, the $\mathrm{TcPO}_{2}$ in the affected limb $(40.5 \mathrm{mmHg})$ was significantly lower than that in the non-affected limb (50.7 mmHg; $\mathrm{P}<0.01$; Table 2).

Subgroup comparison according to the affected legs of various stages versus the unaffected leg (Table 3) showed a statistically significant difference between the unaffected leg and legs with stage $\mathrm{C} 5$ to $\mathrm{C} 6$ disease $(\mathrm{P}<0.01)$. The difference in $\mathrm{TcPO}_{2}$ was statistically non-significant for $\mathrm{C} 4$ disease. However, the values were lower in legs with $\mathrm{C} 5$ or $\mathrm{C} 6$
Table 4. Range of $\mathrm{TcPO}_{2}$ in clinical stages 4, 5, 6 and normal limb (unit: $\mathrm{mmHg}$ )

\begin{tabular}{|c|c|c|}
\hline \multirow{2}{*}{ Clinical stage } & \multicolumn{2}{|c|}{ Position } \\
\hline & Supine & Dependent \\
\hline \multicolumn{3}{|l|}{ Stage $4 \mathrm{TcPO}_{2}(\mathrm{n}=23)$} \\
\hline Mean \pm SD & $26.57 \pm 13.59$ & $44.83 \pm 13.05$ \\
\hline Median (range) & $28.00(6-65)$ & $49.00(22-75)$ \\
\hline SEM & 2.97 & 2.85 \\
\hline \multicolumn{3}{|l|}{ Stage $5 \mathrm{TcPO}_{2}(\mathrm{n}=19)$} \\
\hline Mean \pm SD & $16.63 \pm 8.80$ & $35.47 \pm 9.95$ \\
\hline Median (range) & $18.00(4-32)$ & $35.00(15-52)$ \\
\hline SEM & 2.14 & 2.41 \\
\hline \multicolumn{3}{|l|}{ Stage $6 \mathrm{TcPO}_{2}(\mathrm{n}=54)$} \\
\hline Mean $\pm S D$ & $24.22 \pm 10.43$ & $40.43 \pm 12.00$ \\
\hline Median (range) & $24.50(1-54)$ & $43.00(4-60)$ \\
\hline SEM & 1.61 & 1.85 \\
\hline \multicolumn{3}{|c|}{ Normal limb $\mathrm{TcPO}_{2}(\mathrm{n}=96)$} \\
\hline Mean $\pm S D$ & $32.05 \pm 11.16$ & $50.74 \pm 11.89$ \\
\hline Median (range) & $30.00(5-74)$ & $50.00(20-85)$ \\
\hline SEM & 1.25 & 1.33 \\
\hline
\end{tabular}

disease, both in the supine and dependent positions (Table 3). In the supine position, a statistically significant decrease in mean $\mathrm{TcPO}_{2}$ values was observed between $\mathrm{C} 4$ and $\mathrm{C}$, but not between $\mathrm{C} 5$ and $\mathrm{C} 6$. This decrease was not significant among stages $\mathrm{C} 4$ to $\mathrm{C} 6$ in the dependent position. The range of $\mathrm{TcPO}_{2}$ values is listed in Table 4.

The $\mathrm{TcPO}_{2}$ had fair accuracy with an area under the receiver operating characteristic curve $>0.7$ for both supine (Fig. 1) and dependent positions (Fig. 2) in detecting advanced $\mathrm{CVl}$, when compared to the unaffected limb. A $\mathrm{TcPO}_{2}$ value of $40 \mathrm{mmHg}$ in the supine position had a sensitivity of 95\% and specificity of 20\% for predicting the diseased state. In the dependent position, a value of $56 \mathrm{mmHg}$ had a sensitivity of approximately $91 \%$, with a specificity of $25 \%$. A cut-off value could not be recommended because the increase in sensitivity was at the expense of specificity and a high false-positive rate. There was a positive correlation between supine and dependent $\mathrm{TcPO}_{2}$ values in both affected (0.839) and non-affected (0.818) limbs (Fig. 3).

\section{DISCUSSION}

The transcutaneous oxygen content is supposed to reflect the microcirculatory state of the underlying tissue, both in health and disease. Its content or partial pressure should decrease with severe disease in $\mathrm{CVl}$, with values being lowest in stage $\mathrm{C6}$, with or without trophic changes. A 


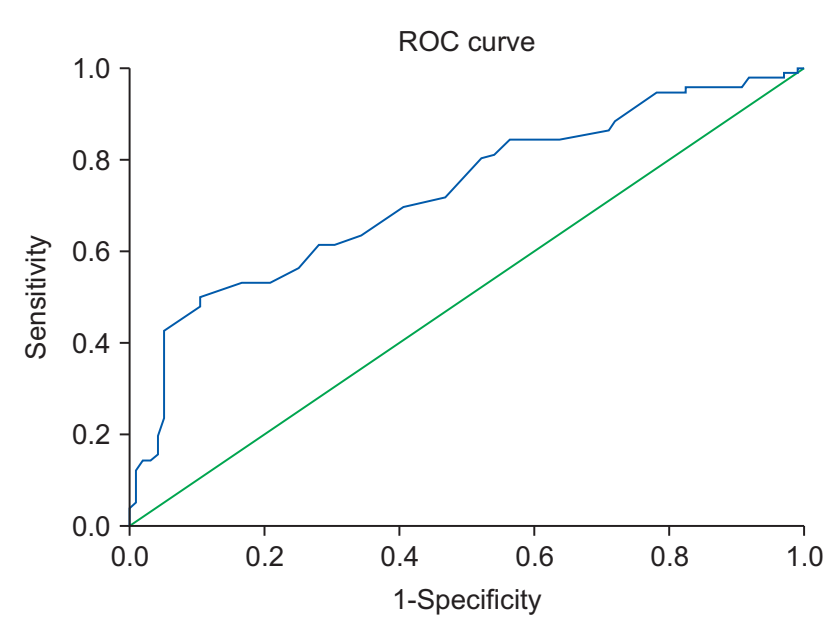

Fig. 1. Receiver operating characteristic (ROC) of supine $\mathrm{TcPO}_{2}$ in predicting disease state. Area under the curve $=0.727$, standard error $=0.036, \mathrm{P}<0.001$.

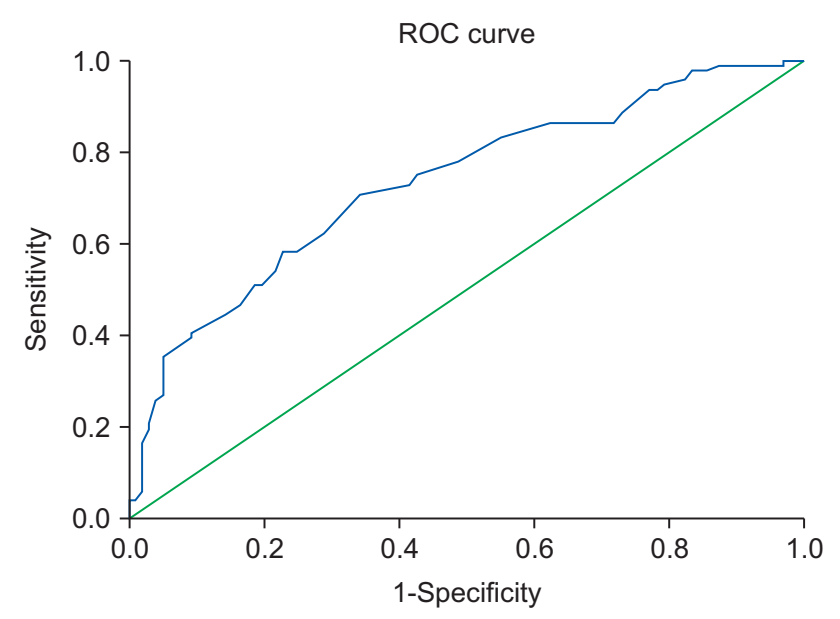

Fig. 2. Receiver operating characteristic (ROC) of dependent $\mathrm{TcPO}_{2}$ in predicting disease state. Area under the curve $=0.733$, standard error $=0.036, P<0.001$.

higher $\mathrm{TcPO}_{2}$ would indicate a better state of health in the tissue. The null hypothesis would state that $\mathrm{TcPO}_{2}$ does not reflect the microcirculation the CVI.

The prevalence of $\mathrm{CVl}$ is higher in females, as seen in many population studies $[9,12]$. However, this study of 96 Indian patients included 85 males (88.5\%) and 11 (11.5\%) females, and the prevalence of CVI was lower in females, which may reflect a selection bias. The prevalence of CVI increases with age [13]. In this study, 59.4\% of patients were above the age of 40 years. $\mathrm{TcPO}_{2}$ had fair accuracy in detecting advanced stage $\mathrm{CVI}$ ( $\mathrm{C} 4$ to $\mathrm{C} 6$ ) when compared to the unaffected limb. The values were significantly lower in the $\mathrm{C5} / \mathrm{C} 6$ disease, both in the supine and dependent positions. Segregated by stage, $\mathrm{TcPO}_{2}$ was significantly lower in C5/C6 than in the unaffected limb. C6 had a statistically

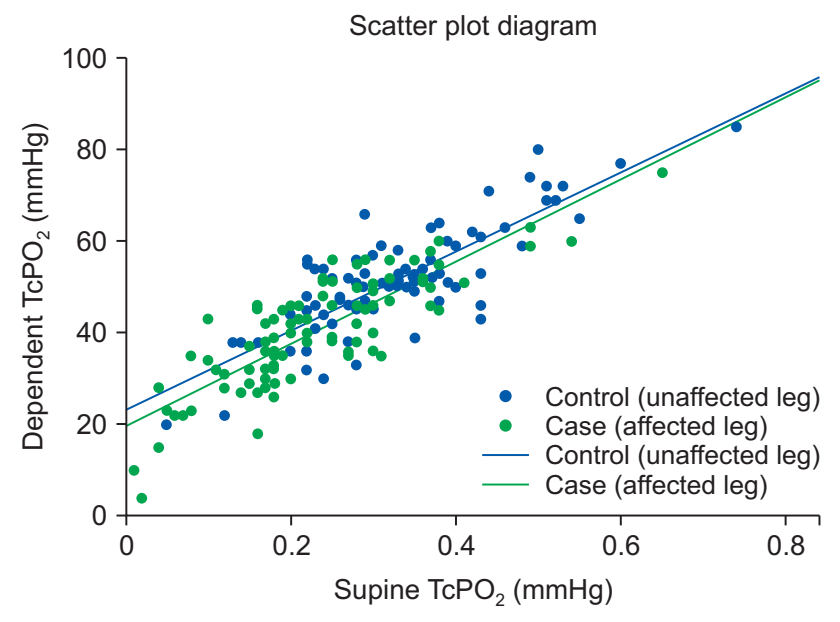

Fig. 3. Scatter plot of supine and dependent $\mathrm{TcPO}_{2}$ values in affected and unaffected legs. Control $R^{2}$ linear $=0.669$. Case $\mathrm{R}^{2}$ linear $=0.703$.

non-significantly higher $\mathrm{TcPO}_{2}$ than that of $\mathrm{C} 5$. There was a significant decrease in $\mathrm{TcPO}_{2}$ from $\mathrm{C} 4$ to $\mathrm{C} 5$. This is expected because scarred or healed lesions are known to have low oxygen tension.

In a study by Franzeck et al. [14], $\mathrm{TcPO}_{2}$ was measured and correlated with video microscopy to examine the microvasculature. The mean $\mathrm{TcPO}_{2}$ of control group was $56.8 \mathrm{mmHg}$, and that of affected group was $47.7 \mathrm{mmHg}$. The difference was not statistically significant $(\mathrm{P}>0.05)$. In this study, $\mathrm{TcPO}_{2}$ was measured at the site of maximal change, which reflects poor microcirculation internally.

Barnikol and Pötzschke [15] reported a comparative study of the mean value of four $\mathrm{TcPO}_{2}$ measurements in patients with $\mathrm{C} 6 \mathrm{CVl}$; the mean $\mathrm{TcPO}_{2}$ value was significantly lower in the $\mathrm{C} 6$ disease group than in the control group (17.9 vs. $63.0 \mathrm{mmHg}$, respectively). In this study, the mean $\mathrm{TcPO}_{2}$ was also significantly lower in the $\mathrm{C} 6$ disease group than in the control group (24.2 vs. $32.1 \mathrm{mmHg}$, respectively). The greater difference in the mean values in the study by Barnikol and Pötzschke [15] was probably due to four measurements taken around the ulcer, which is more reliable than a single measurement. However, even a single measurement at the site of greatest skin change was statistically significant, as shown in this study. Recently, $\mathrm{TcPO}_{2}$ was also studied in post-thrombotic syndrome (PTS) by Cuen-Ojeda et al. [16], who found low $\mathrm{TcPO}_{2}$ levels in severe cases of PTS.

A cutoff value of $40 \mathrm{mmHg}$ in the supine position had 95\% sensitivity and 20\% specificity; the same cutoff in the dependent position had a 50\% sensitivity and $80 \%$ specificity. A particular cutoff value could not be recommended, as the increase in sensitivity came at the expense of specificity and a high false-positive rate. The study also 
found that the $\mathrm{TcPO}_{2}$ was significantly lower in the supine position than in the dependent position, thus demonstrating the effect of limb position on $\mathrm{TcPO}_{2}$ values.

There are several limitations to this study. The number of patients in each stage of advanced CVI was not equal, with the majority of patients in the C6 stage. A single periarticular $\mathrm{TcPO}_{2}$ measurement may not provide representative information concerning the oxygen status of the entire wound due to oxygen inhomogeneity. Multiple same-limb control measurements were not performed. However, this was primarily done to determine whether $\mathrm{TcPO}_{2}$ correlates with the severity of CVI. In addition, repeated measurements would take time and add expense due to the need for new electrodes, which is difficult in resource-limited settings. There could be a potential selection bias, as the location for $\mathrm{TcPO}_{2}$ measurement was based on the subjective assessment of area of maximum skin change. Peripheral arterial disease was ruled out in all patients clinically with the presence of palpable pulses and normal ankle-brachial pressure index; however, an arterial duplex ultrasound was not performed in all patients.

In a limb affected by $\mathrm{CVl}$, the $\mathrm{TcPO}_{2}$ was significantly lower in the $\mathrm{C} 5 / \mathrm{C} 6$ stage than in the unaffected limb, with a definite effect of limb positioning on $\mathrm{TcPO}_{2}$ values. Since $\mathrm{TcPO}_{2}$ was lowest in the $\mathrm{C} 5$ stage, its role or clinical relevance in this stage is doubtful, as scarred tissue will obviously have low oxygen tension. The statistically significantly lower value than that in the unaffected limb and the decrease in $\mathrm{TcPO}_{2}$ from $\mathrm{C} 4$ to $\mathrm{C} 6$ (though not statistically significant) provides a direction for studies focusing on single $\mathrm{TcPO}_{2}$ value as a prognostic tool in relation to interventions and as a marker for $\mathrm{C} 6$ disease. An increase in $\mathrm{TcPO}_{2}$ following intervention could predict the efficacy of the intervention. Future studies using $\mathrm{TcPO}_{2}$ to compare interventions or objectively assess improvement after an intervention can be conducted.

\section{CONCLUSION}

$\mathrm{TcPO}_{2}$ is a non-invasive test that can be used with a single value in an outpatient setting to assess clinical progression (worsening or improvement) of CVl. This is the first study in an Indian population focusing on the relevance of $\mathrm{TcPO}_{2}$ in advanced CVl for prognostication.

\section{ACKNOWLEDGEMENTS}

We would like to thank Dr. Grace Rebecca for help in statistical analyses and Dr. Aubin Mathew Varghese in preparation of this manuscript.

\section{FUNDING}

This study was supported by internal fluid research grant (No. 8994).

\section{CONFLICTS OF INTEREST}

The authors have nothing to disclose.

\section{ORCID}

\author{
Ludia John \\ https://orcid.org/0000-0001-7714-8167 \\ Albert Abhinay Kota \\ https://orcid.org/0000-0002-4313-803X \\ Vimalin Samuel \\ https://orcid.org/0000-0001-5520-0286 \\ Prabhu Premkumar \\ https://orcid.org/0000-0002-0796-5644 \\ Dheepak Selvaraj \\ https://orcid.org/0000-0002-3472-3528 \\ Edwin Stephen \\ https://orcid.org/0000-0002-9615-3444 \\ Sunil Agarwal \\ https://orcid.org/0000-0002-8012-8762 \\ Pranay Gaikwad \\ https://orcid.org/0000-0002-8124-5813
}

\section{AUTHOR CONTRIBUTIONS}

Concept and design: AAK, SA. Analysis and interpretation: LJ, AAK, SA. Data collection: LJ, AAK. Writing the article: LJ, AAK. Critical revision of the article: LJ, AAK, VS, PP, DS, ES, SA, PG. Final approval of the article: all authors. Statistical analysis: LJ, AAK. Obtained funding: LJ, AAK. Overall responsibility: AAK.

\section{REFERENCES}

1) Langer V. Leg ulcers: an Indian perspective. Indian Dermatol Online J
2014;5:535-536.

2) Shukla VK, Ansari MA, Gupta SK.
Wound healing research: a perspective from India. Int J Low Extrem Wounds 
2005;4:7-8.

3) Selvaraj D, Kota A, Premkumar P, Stephen E, Agarwal S. Socio-demography and clinical profile of venous ulcers. Wound Med 2017;19:1-4.

4) Kelechi TJ, Michel Y. A descriptive study of skin temperature, tissue perfusion, and tissue oxygen in patients with chronic venous disease. Biol Res Nurs 2007;9:70-80.

5) Roszinski S, Schmeller W. Differences between intracutaneous and transcutaneous skin oxygen tension in chronic venous insufficiency. J Cardiovasc Surg (Torino) 1995;36:407-413.

6) Wütschert R, Bounameaux H. Determination of amputation level in ischemic limbs. Reappraisal of the measurement of TcPo2. Diabetes Care 1997;20:1315-1318.

7) Mani R. Transcutaneous measurements of oxygen tension in venous ulcer disease. Vasc Med Rev 1995;6:121131.
8) Poredos P, Rakovec S, Guzic-Salobir B. Determination of amputation level in ischaemic limbs using tcPO2 measurement. Vasa 2005;34:108-112.

9) Beebe-Dimmer JL, Pfeifer JR, Engle JS, Schottenfeld D. The epidemiology of chronic venous insufficiency and varicose veins. Ann Epidemiol 2005;15:175-184.

10) Dooley J, Schirmer J, Slade B, Folden B. Use of transcutaneous pressure of oxygen in the evaluation of edematous wounds. Undersea Hyperb Med 1996;23:167-174.

11) Porter JM, Moneta GL. Reporting standards in venous disease: an update. International Consensus Committee on Chronic Venous Disease. J Vasc Surg 1995;21:635-645.

12) Callam MJ. Epidemiology of varicose veins. Br J Surg 1994;81:167-173.

13) Eberhardt RT, Raffetto JD. Chronic venous insufficiency. Circulation 2005;111:2398-2409.
14) Franzeck UK, Haselbach $P$, Speiser D, Bollinger A. Microangiopathy of cutaneous blood and lymphatic capillaries in chronic venous insufficiency (CVI). Yale J Biol Med 1993;66:37-46.

15) Barnikol WK, Pötzschke H. A novel, non-invasive diagnostic clinical procedure for the determination of an oxygenation status of chronic lower leg ulcers using peri-ulceral transcutaneous oxygen partial pressure measurements: results of its application in chronic venous insufficiency (CVI). Ger Med Sci 2012;10:Doc11.

16) Cuen-Ojeda C, Anaya-Ayala JE, Laparra-Escareno H, García-Alva R, Lizola $\mathrm{R}$, Arzola LH, et al. Measurement of transcutaneous oxygen pressure in patients with post-thrombotic syndrome: findings and possible clinical applications. Vascular 2020;28:172176. 